\title{
Reflections on the What of Learner Autonomy
}

\author{
Masoud Zoghi ${ }^{1} \&$ Hamid Nezhad Dehghan ${ }^{2}$ \\ ${ }^{1}$ Department of English Language Teaching, Ahar Branch, Islamic Azad University, Ahar, Iran \\ ${ }^{2}$ Tabriz Branch, Islamic Azad University, Tabriz, Iran \\ Correspondence: Masoud Zoghi, Km.2 Ahar - Tabriz Road, Ahar Azad University Complex, Ahar, Iran. E-mail: \\ m-zoghi@iau-ahar.ac.ir
}

Received: December 2, 2011

Accepted: January 10, $2012 \quad$ Published: June 1, 2012

doi:10.5539/ijel.v2n3p22

URL: http://dx.doi.org/10.5539/ijel.v2n3p22

\begin{abstract}
The critical role of the learner in the language learning process has been stressed within recent approaches in the humanities and language studies. For this reason the term learner autonomy is now a very fashionable word in the fields of language learning and teaching. On a general note, there are two dominant approaches to knowledge and learning, each of which adopts a different stance on learner autonomy. These two opposing camps are usually referred to as positivism and constructivism. Although learner autonomy is welcomed by many educators, there is not a broad consensus of opinion on its definition. In this article attempts have been made to show that learner autonomy is a dual conceptualization which incorporates the notions of dependence and independence. The ideology driving the view of learner autonomy presented here has been that learner autonomy should be achieved through the tenets of the scaffolding theory proposed by Bruner (1988). Additionally, the authors will highlight the factors involved in building up autonomy in students. It is hoped that the way we go about dealing with this concept may shed some light on the labyrinth that we are all in, namely the field of ELT.
\end{abstract}

Keywords: positivism, learner autonomy, constructivism, scaffolding theory

\section{Introduction}

Education is at the heart of a modern society. As Nunan (1999, p. 4) believes "For many people, education is about knowledge". The most controversial debate over the last century has been on the way that knowledge is acquired. For the sake of simplicity, let us look at theories of knowledge and learning in terms of two opposing camps. In one of these camps, there are "those who believe that the function of an educational system is the transmission of a received body of facts, values, and procedures for conceptualizing and adding to that body of knowledge" (ibid.). However, in the other camp much attention has been given to the learner. For most people "the function of an educational system is to create the conditions whereby learners might generate their own skills and knowledge" (ibid.). In simpler terms, according to these people learners are not just like empty vessels waiting to be filled, or they are not the ones who things merely happens to them; but rather, they are the ones who make things happen. They have responsibility for and take control over what they do i.e. they are autonomous.

The concept of autonomy seems to be semantically complex, because it entails some sort of freedom, which not many educators have reached broad agreement on its definition. The current disagreement has prompted us to take up its definition and express our own understanding of the termin the next section of the article.

\section{Defining Autonomy}

The meaning of autonomy includes, to quote the Random House Dictionary (1987, p. 141), "independence or freedom, as of the will or one's action". To come to a better understanding of the term we need to go through the relevant literature. Holec (1981, p. 3) contends that autonomy is "the ability to take charge of one's learning". Accordingly, autonomous learners are thought, as Little (1991, p. 3) holds, to have "the capacity for detachment [from the teacher], critical reflection, decision-making and independent action". Reviewing Dam's study (1990), one is also to infer that an autonomous learner is the one who is responsible for everything in class i.e. $\mathrm{s} /$ he independently chooses aims and purposes, materials, instructional methods, tasks, and evaluation methods. Various definitions of autonomy can be found in the related literature. The term has been used interchangeably with other terms such as independence (Sheerin, 1991), language awareness (Lier, 1996), self-direction (Candy, 
1991), and andragogy (Knowles, 1980). As was mentioned earlier, the concept of autonomy has a denotation of freedom. Then, the big question that may now be asked is: Does autonomy mean the freedom from the teacher, the textbook, the syllabus and even the freedom to choose not to learn? It seems that the answer is a resounding "NO". Widdowson (1990, p. 151) puts it quite rightly arguing that "No freedom is possible unless there are limits to define it ". He goes on noting that "the constraints on learning are in effect the essential conditions of its existence" (ibid.). Therefore, autonomous learning cannot carry the implication of setting the learner free from, for instance, the teacher; but rather it implies providing freedom within self, i.e. providing room for individual manoeuvre. In this way we can enhance the learners' capacity to go beyond their normal limits of personal heritage.

Form what we have already said, it could be manifest that we are not arguing for an "unbridled classroom" where the teacher plays no significant role. In our view the teacher is the one who paves the ground for the learner to choose the most appropriate modus operandi in his or her dealing with the process of learning. In fact, there is a constant interaction between the teacher and the learner in the process of learning in which both make decisions along with continuous planning and monitoring of activities. In this way, the learner becomes an active manager of his or her own learning and the teacher's job is more like a facilitator of the process, who creates room for promoting autonomous learning.

As was mentioned earlier, the concept of autonomy seems to be semantically complex; it naturally denotes independence. Although we all strive for being autonomous, the next key question raised here is whether this is really feasible. As social creatures, we depend on one another in certain ways. In reality, we need to be autonomous and much in the same way we need to be dependent. These are two basic human needs. In our view, autonomy is a paradox to which we cannot attribute an absolute value. In fact, it is something within the individual.

This implies that learners should be both independent and dependent when exercising their autonomy. So the true meaning of autonomy is not being unbridled and is not a complete irrational freedom to do anything, but rather having the ability for individual manoeuvre, namely the power to make informed choices through self-discovery.

\section{The Philosophy of Autonomous Learning}

Perhaps the easiest way to look at the philosophies of learning and knowledge is by putting the two dominant approaches on a continuum with positivism on the one end, constructivism on the other, and along which various approaches may be placed.

Positivism, which still manipulates our current educational system, is based on the assumption that knowledge is objective reality, and the teacher is considered to possess this objective reality. As a result, according to Benson and Voller (1997, p. 20) learning is "the transmission of knowledge from one individual [the teacher] to another [the student]". We might draw an analogy between such an educational system and a conveyor belt, that is, the students are more like items on the belt being conveyed with no will of their own, and waiting to be worked on by the person in charge. This is the way most of us as teachers still go about teaching in the second millennium and the way we still maintain and enhance our traditional classrooms.

The opposite end on the continuum is called constructivism. The Website of Southwest Educational Development Laboratory (SEDL) reports that "constructivism can be traced at least to the 18th century and the work of the Neapolitan philosopher Giambattista Vico, who held that humans can only clearly understand what they have themselves constructed". Experiencing and discovering are two guiding principles of constructivism. Although our experiences play a very important role in shaping our own understanding of the world, the fundamental principle of constructivism is considered to be discovery (Piaget, 1973). Piaget advocates that "to understand is to discover, or reconstruct by rediscovery" (for more information see Piaget, 1973 and Dewey, 1966). Therefore, it can be inferred that learning, according to constructivism, is a search for meaning and the ultimate goal of learning is meaning construction, rather than committing the right answers to memory and rephrasing other people's meaning.

This short literature review reveals that positivism is incongruent with, and even runs counter to the development of autonomous learning in which learners, as Benson and Voller (1997) contend, are authors of their own world. Learners, in positivism, simply react to various stimuli provided by the teacher, rather than taking an active role and generating their own ideas. In constructivism, learning is not simply a matter of rote memorization; "it is a constructive process that involves actively, seeking meaning from (or even imposing meaning on) events" (Candy, 1991, p. 271). One thing is manifest that we still educate our students as if preparing them for a machine life and assembly line work. Teaching through the principles based on positivism, that is, following rigid academic agendas works no more. To say our scholastic curriculum is obsolete and outmoded is putting it nicely. 
Today's children need to learn the skills that will help them in today's society. They need to learn how to make decisions on their own and work well with others. To achieve this goal, they need to learn how to take control over and responsibility for their own learning.

\subsection{Learner Strategies and Learner Autonomy}

It is agreed that individuals have their own attributes which can influence the learning process. Every single student has a different individual profile. In fact, each of our students is a unique cluster of characteristics and they carry their own "personal baggage" to class. One component of this personal baggage is motivation that can be affected by the independence (autonomy) the learner experience in class. It is necessary to re-emphasize that autonomy does not have an absolute value i.e. it is more like a process towards which learners work. And in order to develop learner autonomy there are certain factors which should be taken into consideration. A key factor playing an important role among others, within such a process is the learners' learning strategies.

The term learning strategy has been defined by many scholars. Chamot, Barnhardt, El-Dinary, and Rubbins (1999) define this term as techniques that learners apply to facilitate and enhance the effectiveness of a learning task. Traditionally classroom teachers have provided assistance (which will be discussed later in this article under the heading of scaffolding theory) by modeling the learning strategies and then fading farther in the background gradually shifting the learning responsibilities to students as learners gain competence.

\subsection{Building up Learner Autonomy}

The ideology driving the view of learner autonomy presented in this article has been that the term autonomy is a dual conceptualization, which is to be considered as a necessary condition for learning to take place. As was mentioned earlier, within the term autonomy we, for the reasons that were offered, can infer two binary opposites: independence and dependence. Thus, in our classrooms learners feel the need for independence and its opposite, that is, the need for dependence. If we are to implement learner autonomy within our classrooms, we then need to adopt such a dependence / independence framework, as depicted in Figure 1.

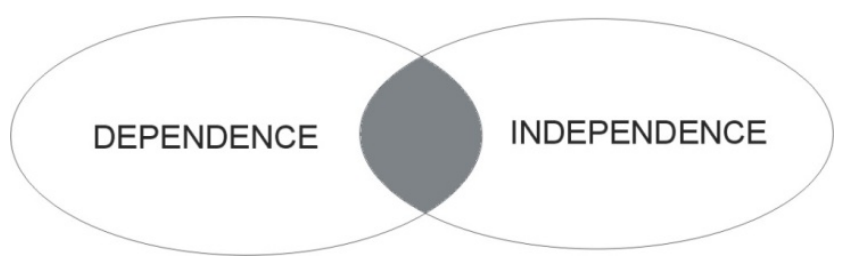

Figure 1. The dependence / independence framework for learner autonomy

The shaded area is where the learner autonomy lies. If we fall back on to the dependence side, learners will be dependent on us to a great extent; much in the same way if we turn to the independence side it would mean that learners will be independent of us in one way or another. Neither works. The possible solution is to be keeping the balance. This balancing of independence and dependence refers to the theoretical stance that has been termed as scaffolding by Bruner (1983). Literally, scaffolding means using poles and boards round a building that is being built, painted, or repaired. Pressley, Hogan, Wharon-McDonald, and Mistretta (1996) view scaffolding as providing assistance to learners on an as-needed basis and as their competence to do a task increases, assistance is faded. The major theme in the theoretical framework of Bruner's scaffolding is that we build a structure round learners who are involved in the learning process, and we gradually take it away until we become confident that they can stand on their own two feet.

\subsection{Language Teaching Methods and Learner Autonomy}

To provide backbone for our discussion at this stage, it is worth using the aforementioned framework to look into a couple of teaching methods which are very often used in language teaching. We will go through these methods in order to find out how compatible they are with our view of autonomy i.e. the dependence / independence framework.

No matter what aspect of the language is being taught, a language lesson usually consists of three main stages. These stages are presentation, practice and production. This has conventionally become known as the "PPP" teaching model. Each of these stages serves a different purpose and one is incomplete without the others. The presentation stage is dedicated to the task of imparting knowledge about the lesson to the students. Everything that the students need to know about the subject that is being taught ought to be transferred to them through the presentation stage of the language lesson. In the practice stage the new language is manipulated. The practice stage reinforces the materials that have been potentially mentalistically absorbed during the presentation stage of 
the lesson. And finally in the production stage students are allowed to produce the new language in more or less free way. It should be noted that the role of the teacher, according to Abghari (1996), in the presentation stage is that of an informant, in the practice stage that of a guide and in the production stage that of a mere observer. Therefore, we would argue that through the first two stages the teacher's job is to only provide some degree of dependence and in the final stage he or she is expected to simply give his or her students some degree of independence.

Some methods, like grammar translation, made the assumption that little more than presentation was required for learning to take place. In terms of the presentation $\rightarrow$ practice $\rightarrow$ production (PPP) sequence we might label such models as $\mathrm{P}_{--}-$; the dashes signify the absence of the second and third stages.

Audiolingualism, and some other approaches, in all its countless and highly widespread manifestation, often has presentation and practice ( $\mathrm{PP}-$ ), but tends to omit free production. The assumption is that this final stage is simply not required - learners who have drilled all the patterns of the language will be able to use that knowledge in natural ways outside the classroom. But not so! Considering the fact that learners cannot use what they have learned in real time performance, the role of the final P in the PPP sequence becomes striking. In fact, through such teaching methods students are just given support (dependence) rather than being challenged (independence).

The imputed failure of such traditional teaching methods is a major reason why some have abandoned them in favor of the newly developed methods. Most of the new approaches to language teaching like task-based or process-based approaches, one might argue, are examples of - $-\mathrm{P}$, namely they avoid formal presentation and practice and rely only on free production to achieve mastery. However, the result is obvious again. Learners who are left alone and are challenged from the very beginning of the class will certainly develop a sense of insecurity due to too much independence.

Upon some reflection, we observe that neither a PP - model, nor a - P model seems to be successful. For obvious and perfectly sensible reasons that we have already considered, there seems to be an urgent need to develop a method that is very much a three $\mathrm{P}$ one and is compatible with the view of learner autonomy that we have developed during writing this paper.

From what was said above, it becomes clear that the concept of learner autonomy lies in the idea of scaffolding which we have looked into throughout this writing as a dependence/independence framework. It is quite true that we all value and want dependence and independence. Bearing this in mind, we, as educators, ought to attempt to keep the balance, otherwise we might run the risk of demotivating our learners either by too much dependence or by too little independence and vice versa. Using such a framework within our profession is seemingly the core of the process of learning and teaching for autonomy.

\section{Concluding Remarks}

This article is far from comprehensive, for we just scratched the surface of the concept. There are certainly many pieces of this puzzle termed learner autonomy missing. Take the role of the curriculum or textbooks for example in promoting autonomy. Most importantly, we feel the need for further studies on finding more practical ways and guidelines for the realization of the dependence/independence framework in class.

In sum, what permeated this article is the belief that the notion of learner autonomy should be placed on a continuum with the dependence on the one end and the independence on the other. Taking this into account, we can conclude that learner autonomy falls somewhere in-between. And it is our duty to work hard to maintain the reconciliation.

In closing, it seems appropriate to end this writing with the old saying: you can please some of the people all of the time, all of the people some of the time, but you can't please all of the people all of the time. Even though this appears to be a normal state of things, a good teacher is someone who can break the rules and make everyone pleased all of the time in the classroom.

\section{References}

Abghari, H. (1996). A Handbook of Teaching English as a Foreign Language. Tehran: Shokouh's Language Institute.

Benson, P., \& Voller, P. (1997). Autonomy and Independence in Language Learning. Harow: Longman.

Bruner, J. (1983). Child's Talk: Learning to Use Language. New York: Norton.

Candy, P. C. (1991). Self-direction for Lifelong Learning. California: Jossey-Bass. 
Chamot, A.V., Barnhardt. S., El-Dinary, P. B., \& Robbins, J. (1999). The Learning Strategies Handbook. White Plains, NY: Addison Wesley Longman.

Dam, L. (1990). Learner Autonomy in Practice. In Gathercole, I. (Ed.), CILT. Great Britain: Bourne Press.

Dewey, J. (1966). Democracy and Education. New York: Free Press.

Holec, H. (1981). Autonomy \& Foreign Language Learning. Oxford: OUP.

Knowles, M. S. (1980). The Modern Practice of Adult Education: From Pedagogy to Andragogy. Chicago: Follett.

Little, D. (1991). Learner Autonomy. 1: Definitions. Lssues \& Problems. Dublin: Authentik.

Nunan, D. (1999). Second Language Teaching and Learning. Boston: Heinle \& Heinle.

O’Mally, J. M. et al. (1985). Learning Strategy Application with Students of English as a Second Language. TESOL Quarterly, 19, 557-584. http://dx.doi.org/10.2307/3586278

Oxford, R. (1990). Language Learning Strategies: What Every Teacher Should Know. N.Y: Newbury House Publishers.

Piaget, J. (1973). To Understand Is to Invent. New York: Grossman.

Press, M., Hogan, K., Wharton-McDonald, R., \& Mistretta, J. (1996). The challenges of instructional scaffolding: The challenges of instruction that supports student thinking. Learning Disabilities Research \& Practice, 11(3), 138-146.

Richards, J. C., \& Platt, J. (1992). Longman Dictionary of Language Teaching and Applied Linguistics. Essex: Longman.

Rubin, J., \& Wenden, A. (1987). Learner Strategies in Language Learning. New Jersey: Prentice Hall.

Sheerin, S. (1991). State of the art: self - access. Language Teaching, 24(3), 153-157.

Skehan, P. (1998). A Cognitive Approach to Language Learning. Oxford: OUP.

The Random House Dictionary of the English Language (2nd ed.) (1987). New York: Random House.

VanLier, L. (1996). Interaction in the Language Curriculum.Awareness, Autonomy \& Authenticity. Harlow: Longman.

Winddowson, H. G. (1990). Aspects of Language Teaching. Oxford: OUP.

\section{Note}

Note 1. A version of this paper was originally presented as a working paper at the International Conference on "Higher Education for the $21^{\text {st }}$ Century" in Curtin University of Technology, Sarawak Campus Malaysia. 